УДК 811.161 .1

\title{
А.В. Чистяков
}

\section{РАЗВИТИЕ ГОСУДАРСТВЕННОСТИ В РОССИИ ХVIII ВЕКА И ФОРМИРОВАНИЕ НОВОГО ТИПА ДЕЛОВОЙ ПИСЬМЕННОСТИ}

Статья посвящена вопросу развития деловой письменности как самостоятельного стиля официального документооборота в России. На протяжении столетий документы составлялись на языке, приближенном к разговорному и содержащем индивидуальные речевые особенности составителя. Так продолжалось до XVIII в., когда Петр I ускорил централизацию государства и реорганизовал систему государственного управления. Эти преобразования вызвали необходимость систематизировать документооборот, унифицировать законодательные акты. Закономерно, что подобная деятельность привела к упорядочиванию и языка документов. Как показано в статье, на протяжении XVIII в. можно наблюдать две основные тенденции в развитии делового языка: 1) активное обогащение лексики и речевых оборотов за счет заимствований и терминологизации, вызванное развитием разнообразных сторон общественной жизни; 2) обособление жанров, регламентация формуляра документов и активное формирование терминологии. Этот процесс, начавшийся в Петровскую эпоху, продолжался много десятилетий и не был закончен при Екатерине II.

Ключевые слова: деловая письменность, кодификация, норма, стиль, история русского языка.

DOI: $10.35634 / 2412-9534-2021-31-3-438-448$

\section{Введение}

Письменные памятники остаются объектом лингвистического исследования уже на протяжении более двух веков, и сам этот факт свидетельствует в равной степени как о значимости работы в данном направлении, так и об огромном потенциале, заключенном в исторических текстах и представляющем все новые и новые аспекты изучения.

Такое положение, занимаемое деловой письменностью, обусловлено ее особым, неоднозначно оцениваемым положением в системе русского языка. Исследователи, обращающиеся к изучению исторических памятников, старались выявить их характерные черты и особенности, определить положение, занимаемое деловой письменностью в общей системе русского языка, раскрыть характер ее взаимоотношений с языком литературным.

Вопрос о роли и значении деловой письменности в истории русского языка оставался на протяжении ее изучения самым спорным и неоднозначным. Соответственно, изучение языка памятников письменности в тот или иной исторический период затруднительно без экскурса в историю изучения предшествующих этапов ее развития.

\section{История изучения вопроса}

Лингвистами достаточно полно изучены памятники X-XVII вв. и их состав, поскольку они позволяют проследить динамику развития деловой письменности от зарождения к обретению системности. Собирание древних текстов, сличение их вариантов, детальный лингвистический и исторический анализ языкового материала требовали колоссальных усилий и закладывали основы изучения письменных памятников.

А.Х. Востоков издавал неизвестные ранее памятники, на основе книжных элементов которых создал «Грамматику церковнославянского языка» и «Словарь церковнославянского языка», а лексику народного языка собрал по региональным памятникам, подготовив «Опыт областного великорусского словаря», который в дальнейшем был продолжен и доработан И.И. Срезневским. Параллельно исследователь составлял словарь древнерусского языка на материале памятников приказной письменности, в том числе открытых им самим, а также написал ряд трудов по истории русского языка. А.И. Соболевский продолжил изучение памятников в новом аспекте, исследуя их как образцы диалектной словесности.

Исследователи затрагивали вопросы исторических текстов в связи с изучением общеязыковых явлений, как важный компонент в построении своих научных теорий. Под влиянием разработок Я. Гримма к древним текстам обращался Ф.И. Буслаев. Он составил труд «О преподавании отечест- 
венного языка», в магистерской диссертации «О влиянии христианства на русский язык. Опыт истории языка по Остромирову Евангелию» осветил скорее культурно-исторические аспекты языка, нежели строго лингвистические, а в 1861 г. издал обширный труд «Исторические очерки русской народной словесности и искусства», также не лежащий всецело в сфере проблем языкознания. Автор рассматривает здесь культуру народа через призму духовной и языковой традиции.

Уже на первых этапах отечественной лингвистики становится своеобразной традицией при изучении различных уровней языка, особенно с исторической позиции, основываться на летописях, грамотах и иных жанрах старинных манускриптов. Среди многочисленных исследователей памятников этого периода можно назвать, например, А. А. Шахматова и его работы «Обозрение русских летописных сводов XIV-XVI вв.», «Исследование о двинских грамотах XV в.», «Исследование о языке новгородских грамот XIII и XIV века». А.А. Шахматов заявил о себе как о талантливом и ярком лингвисте, специализирующемся на исторической грамматике, диалектологии, текстологии, фонетике, морфологии и синтаксисе. Скрупулезные исследования грамот, бережное обращение со всеми фактами прошлого, вдумчивые работы по генезису «наречий» русского языка, их истории и развитию во взаимосвязи с народом как его носителем, а также культурой, не оставляют сомнений в широте его научных взглядов и системном, комплексном подходе к изучению исторического наследия, что видно, в частности, в его работах «Исследование о двинских грамотах XV в.» и «Исследование о языке новгородских грамот XIII и XIV века», где ученый дает подробные исторические описания документов и анализирует их лингвистические особенности.

Неразрывно от духовной жизни народа рассматривает бытование языка и Е.Ф. Карский, большое значение придававший региональным компонентам, особенно западнославянским, в формировании общерусского языка. Среди основных его трудов можно назвать «Славянскую кирилловскую палеографию», «Труды по белорусскому и другим славянским языкам», «Грамматику древнего церковнославянского языка сравнительно с русским», где на основе древних памятников, в том числе деловых, изучается развитие письменности.

Историческому изучению русского языка, а также малорусских и белорусских говоров, были посвящены многочисленные работы Н.Н. Дурново, научный интерес которого распространялся и на соотношение фонетики с орфографией. Ученый полагал, что особенности фонетики в текстах отражаются не напрямую, а как отклонения от нормы; в отдельных случаях эти отклонения могут различаться. Кроме того, он отводил особое внимание и вопросу возникновения славянских литературных языков. В статье «К вопросу о времени распадения общеславянского языка» он писал: «Являясь литературным языком разных славянских народов, старославянский язык представлял разные варианты в зависимости от различий в языке пользовавшихся им народов и с течением времени испытал всюду сложную эволюцию, значительно удалившую выросшие из него позднейшие литературные славянские языки, как например, церковнославянский язык болгарской, сербской, русской и чешскоморавской редакции и, наконец, русский литературный язык, от старославянского языка в его первоначальном виде» [7, с. 49]. Н.Н. Дурново издает один из первых в мире «Грамматический словарь», состоящий из терминов, относящихся к лингвистике. По историческим документам ученый занимается русской диалектологией, классифицирует восточнославянские диалекты, отмечая ареал их распространения и особенности.

С серединой XX в. связано имя выдающегося языковеда В.В. Виноградова, научная деятельность которого оказала на все последующее развитие отечественного языкознания значительное влияние. Исследуя вопросы функциональной грамматики в истории языка, ученый затрагивает множество проблем, смежных с предметом его разработок, в том числе касающихся деловой письменности и ее роли в формировании общенационального русского литературного языка: «Изучение литературного языка связывается и с культурной историей данного народа, поскольку такие сопряженные с литературным языком явления, как письменность, литература, наука входят в орбиту и истории культуры» $[4$, с. 101$]$. Он отмечает особую роль письменно-деловой речи в развитии связей между двумя типами древнерусского литературного языка.

Б.А. Успенский в «Кратком очерке истории русского литературного языка (XI-XIX вв.)» говорит о том, что основная проблема языковой ситуации Древней Руси заключается в определении отношения между церковнославянским и русским языком. В широком понимании этого высказывания заключается вопрос о соотношении книжного и разговорного языка. Исследователь обозначает существование диглоссии, которую определяет как «такой способ существования двух языковых систем в рамках од- 
ного языкового коллектива, когда функции этих двух систем находятся в дополнительном распределении, соответствуя функциям одного языка в обычной (недиглоссийной) ситуации» [19, с. 3]. В дальнейшем происходит преобразование диглоссии в церковнославянско-русское двуязычие в ходе второго и третьего южнославянского влияний, и это приводит к тому, что оба языка объединяются как две самостоятельные системы. Далее такая ситуация закономерно приводит к стремлению осмыслить различие между двумя языками и провести параллель между соответствующими формами, т. е. неким образом кодифицировать русский язык, сделать его нормированным, литературным.

А.И. Горшков говорит о многообразии разновидностей литературного языка, в то же время, С.И. Котков утверждает, что господствовало русское многоязычие при коммуникативно весьма ограниченном (в основном рамками религиозного культа) церковнославянском иноязычии. Однако церковнославянские элементы сравнительно свободно применялись в литературной форме русского языка для выражения тех или иных стилистических оттенков. С.И. Котков придерживался позиции, согласно которой исторический путь русского языка можно проследить лишь через оставшееся нам от предков рукописное наследие, и этот подход определяет его научные интересы. Он собирал региональные памятники, издал труды «Памятники деловой письменности XVII века. Владимирский край», «Лингвистическое источниковедение и история русского языка», «Сказки о русском слове» и др.

У Р.И. Аванесова есть многочисленные замечания, касающиеся роли делового стиля в формировании русского национального языка, который, развиваясь и обогащаясь, становится литературным.

Свой вклад в уточнение вопроса о деловой словесности внесли также и ученые, занимающиеся историей России и общества. Это Б.А. Рыбаков, В.О. Ключевский, П.И. Люблинский и др.

Перечисленных исследователей можно отнести к так называемому «классическому периоду», в центре их внимания было «собирание и издание древних рукописных книг с углубленным историкокультурным комментарием» [6, с. 5]. О.В. Никитин в монографии «Проблемы этнолингвистического изучения памятников деловой письменности», говоря о традиции русского языкознания, выделяет «академический» период, время некоторого «затишья» в 1910-1930-х гг., формальнограмматическое, лексико-семантическое, историко-стилистическое направления в лингвистике, оставляя вне этой классификации фигуру В.В. Виноградова как стоящую особняком [15].

Собственно лингвистическое источниковедение как самостоятельное научное направление, заложившее основы изысканий русской исторической лексикологии и лексикографии, сложилось в 1950-1960-е гг., когда возродился интерес к памятникам традиционного содержания.

В последние десятилетия ученые все чаще для описания выбирают определенную разновидность актов, составленных на определенной территории. Двинские купчие XVI-XVII вв., важские денежные отписи XVI-XVII вв., севернорусские порядные XVII века привлечены к исследованию В.Я. Дерягиным для общей характеристики русской деловой речи и выявления ее локальных особенностей. С.С. Волков подробно проанализировал челобитные XVII в., В.В. Юрасова - десятни XVIXVII вв., Е.К. Абрамова - расспросные речи, И.Б. Токмачева - поручные записи и т. д.

\section{Предпосылки формирования нового типа деловой письменности в XVIII в.}

Возникновение или, по крайней мере, вещественное закрепление делового языка связано с появлением письменности на Руси. Это были законы общего значения, разного рода грамоты и указы частного порядка, получившие четкое выражение в «Русской Правде». Однако одними из первых древнерусских памятников стали договоры русских с греками X в., которые были составлены на греческом языке и лишь впоследствии переведены на русский язык, выражая «зарождавшуюся деловую культуру» [12, с. 9].

Возникнув на прагматической основе, деловая письменность не ограничивалась узкими рамками такого бытования; напротив, в средние века и позднее, обогащаясь и развиваясь за счет активного взаимодействия с различными формами и стилями, пополняя лексический состав за счет заимствований из европейских и иных языков, впитывая некоторые элементы языка разговорного, она получала выражение в различных сферах: в общегосударственных указах и законах, в документах местного значения, в разнообразных литературных жанрах (в письмах, наставлениях, поучениях и др.).

Веками документы усложнялись, становились многочисленнее и разнообразнее, и постепенно повторяемость однотипных жизненных ситуаций приводит к обособлению отдельных видов текстов, в которых начинает проявляться своя специфика, связанная как с особенностями словоупотребления, так и с логически-формальным построением текста, с его стилистическим выделением среди прочих. 
A.Н. Красивова указывает: «C XV в. сведение о том, кто писал текст, становится нормой, а с XVIIXVIII вв. - обязательным реквизитом делового письма. Государственно-приказный язык XV-XVII вв. при всей лексической пестроте - это более нормированный, эталонный язык, чем живая разговорная речь» $[11$, с. 4$]$.

С усложнением политической жизни и государственного аппарата дифференциация и расслоение деловой письменности, некогда однородной, наблюдается все рельефнее, и жанровое своеобразие деловых документов становится стройнее, образуя собственную систему. Такая сонаправленная зависимость делового языка от степени развития государственности и усложнения общественных отношений представляется определяющим фактором в процессе его эволюции. Чем четче прорисовываются связи внутри общности людей и отношения ее с окружающим миром, тем активнее деловая словесность дробится на жанры, призванные охватить по возможности все сферы жизни, тем яснее формируются нормы и правила ее функционирования; происходит постепенное разграничение, в частности, лексического состава в языке, использовавшемся в различных сферах. В это время активно расширяется территория государства, укрепляются не только административные отношения, но также экономические, торговые и правовые; юридические вопросы становятся повседневными. Своеобразными центрами, очагами деловых отношений на периферии становятся, помимо государственных учреждений, монастыри, до наших дней сохранившие уникальные грамоты, в которых отражено многообразие деловой письменности того времени, ее богатство и потенциал.

Уже на раннем этапе развития деловой письменности особое значение получают некоторые обороты и лексемы, характерные именно в данном употреблении. Это термины, обозначающие определенные понятия повседневной жизни и требующие однозначного истолкования, и так называемые клише, характерные для канцелярского письма, и повторяющиеся синтаксические конструкции (например, сложноподчиненные предложения с придаточными условными в указах). Именно наличие общих характерных черт позволяет говорить о становлении, функционировании и развитии деловой словесности как особой традиции словесного искусства.

Предпосылками возникновения языка, каким он становился в XVIII в., судьбой его развития интересовались видные общественные и государственные деятели, которые привлекали культурноисторические материалы в качестве не только лингвистического материала. Таковы, в частности, труды В.Н. Татищева, занимавшегося изучением развития страны и общества по древним памятникам. Интерес Татищева к законам тесно связан с его работой по истории Российской империи. Источниками для этого труда служили древние памятники письменности: новгородские летописи, Никоновский список, церковные хронографы, четьи-минеи. Некоторые из них он получал от Голицына и Волынского, а затем издавал, сопровождая собственными замечаниями и комментариями. Написав исторические замечания о Русской Правде, Татищев составил еще более подробные объяснения к Судебнику и дополнительным законам [18]. Однако особо значимым периодом в развитии делового языка является XVIII в., начало которого ознаменовалось просветительской деятельностью Петра I; процесс «взаимодействия книжно-славянских, собственно русских и западноевропейских лексических элементов, теснейшим образом связанный с наметившимися сдвигами в стилистической системе литературного языка, с развитием новых стилей художественной литературы и стилей деловой речи, характерный для XVII в., в первой трети XVIII в. усиливается» [20. С. 113]. За этот период деловая письменность претерпевает больше изменений, чем за XVI-XVII вв.

Первые годы XVIII столетия во многом были переломными для российской культуры и менталитета. Вводится новый гражданский шрифт, реорганизуется административно-территориальное деление, упраздняются уезды и возникают губернии и провинции, упраздняются приказы, заменяясь коллегиями, образуются новые государственные должности. Обилие законодательных нововведений, касающихся практически всех сфер общества, изменение традиций, привычек и жизненных устоев народа необходимо было, во-первых, довести до населения, а во-вторых, каким-то образом объяснить события нужным образом и убедить в пользе преобразований, воздействуя на формирование нового мировосприятия. С первой задачей справлялись законы, в то время как вторая задача требовала современных решений. Именно в это время, со 2 января 1703 г., издается первая российская печатная газета «Ведомости», заложившая основы периодических изданий и журналистики в целом и выдвинувшая вперед газетно-публицистический функциональный стиль языка. В ней печатались сведения о внешней государственной политике, военные новости, сообщения о торговых и промышленных делах, строительстве, открытии новых производств, мануфактур и заводов, содержались заметки о 
европейской жизни. Об особом значении газеты говорит тот факт, что Петр I лично готовил ее первый номер к изданию, а в дальнейшем принимал деятельное участие в редактировании и отборе материалов вместе с Ф.А. Головиным и кабинет-секретарем А. Макаровым. В монографии «Деловая письменность в истории русского литературного языка» О.В. Никитин отмечает: «Формуляр делового текста - это тот наиболее характерный признак, который участвует и в образовании нового газетно-публицистического стиля. Первое время как раз и происходит опора на старые приказные традиции, их внешние формы языкового выражения более приспособлены к эпохе смешения стилей и манер письменной речи» [13, с. 157]. Таким образом, деловой язык получил при Петре I новую область применения, выполняя актуальные для этого времени задачи государственного значения.

Изменение статуса государства, реорганизация аппарата власти, коренные преобразования в административном устройстве, учреждение различных коллегий и контор выражались непосредственно в деловой словесности, которая, представляя собой функционально-стилевую разновидность языка, стала иметь все возрастающее значение в жизни общества в виде указов, именных и высочайших, грамот, докладов, резолюций, уставов, манифестов и т. д., сама подвергаясь изменениям и, что важнее, регламентации.

Говоря об общих замечаниях по поводу деловой письменности XVIII в., нельзя не сказать о М.Л. Магницком, который был не только известным государственным деятелем, но и талантливым исследователем языка, автором «Краткого руководства к деловой и государственной словесности для чиновников, вступающих в службу». Первым обратившись к этой тематике, он рассматривает три периода в развитии делового языка, делит словесность на три «слога» (законодательный, судный и распорядительный), ставя в соответствие каждому определенные жанры и определяя их существенные черты. Небезынтересны его историко-философские рассуждения об особенностях данного деловой словесности, об ораторском искусстве и человеческих качествах чиновников. Важным замечанием представляется признание им возникновения нового классического делового слога; он признает «фактический уход с историко-культурной и языковой арены многовековой приказной традиции, отчасти ее слияние с иной ветвью деловой письменности, которая стала официальным языком государственного канцелярита» [14, с. 91].

Современник М.Л. Магницкого А.С. Шишков в своих высказываниях, касающихся языкового оформления деловых текстов, призывал употреблять средства русского языка, не принимая обилия заимствований из европейских языков, в частности, из французского, тенденция к чему прослеживалась на рубеже XVIII-XIX вв. Он последовательно придерживался позиции формирования интуитивно понятного, чистого русского языка, призывая подходить к решению этого вопроса с большой осторожностью и вниманием.

\section{Языковые особенности деловой письменности XVIII в.}

В XVIII в. интенсивно осуществляется деятельность по нормализации языка. Проводится реформа графики, направленная на отдаление церковнославянского языка от светской письменности, появляются русские грамматики и орфографические руководства. В «Генеральном регламенте» коллегий Петра I была сформулирована система норм и правил ведения документации. «Образцовые письма» предусматривали правила оформления, обращения, именования, указания чинов и званий в документах, прежде всего, в дипломах, патентах и др. А.Г. Косов указывает, что одним из аспектов стандартизации делового письма является трафаретизация, итогом которой в XVIII в. «явилось создание трафаретов, или формуляров-образцов для отдельных видов документов, причем количество документальных жанров, для которых разрабатывались формуляры-образцы, со временем увеличивалось» [10, с. 8$]$.

В письме В.К. Тредиаковскому 18 февраля 1736 г. В.Н. Татищев выразил требования к языку законов: «1) ...чтоб закон краток и не многими, а паче излишними словами наполнен был <... . 2) чтоб слова были все точные, не странные и сугубо мнительные; 3) речение простое и глаткое, дабы каждому и простейшему так вразумительно было <...> и для того никакое иноязычное слово, ниже реторическое сложении в законах употребляться может» [17, с. 224].

Однако указанные нормы и требования в наименьшей степени затрагивали орфографию. На протяжении веков в деловых текстах отражалась вариативность написания во многих словах. Как отмечает Л.Ф. Копосов, говоря о донациональном периоде, «главными особенностями нормы деловой письменности, отличавшей ее от строгой нормы церковнославянского языка, были нестабильность, быстрое обновление состава варьирующихся элементов, наличие множества написаний, отражающих 
диалектные явления» [11, с. 22]. Это справедливо и по отношению к XVIII в., являющему примеры сосуществования фонетических и традиционных написаний.

Чаще всего такое положение видно в обозначении одних согласных перед другими, глухими или звонкими (разпространение и распространение ${ }^{1}$ [16]), что объясняется тем, что «кодификаторы орфографии XVIII в. стремятся закрепить на письме большое количество традиционных написаний, в том числе и искусственных, церковно-славянских; деловая же письменность по-прежнему ориентирована на живую русскую речь» [8, с. 67]. Вариативность же написания заимствованных терминов (апеляция и апелляция, привилегия и привиллегия) вполне понятна, так как эти слова еще не успели усвоиться русским языком, воспринимаясь порой как варваризмы и не имея еще устойчивого воспроизводства. Основные различия между закрепленными в XVIII в. орфографическими нормами и фактами, отраженными в деловых текстах, Л.Ф. Копосов в монографии «Севернорусская деловая письменность XVII-XVIII вв.» сводит к следующим:

1. Деловая скоропись сохраняет широкую вариативность, в то время как нормы, использующиеся в других функциональных разновидностях письменности и кодифицированные грамматиками, характеризуются тенденциями к установлению единообразных написаний на основе морфологического принципа.

2. Кодификаторы орфографии XVIII в. закрепляют на письме большое количество традиционных написаний, в том числе и искусственных, церковно-славянских; деловая же письменность попрежнему ориентирована на живую русскую речь.

В 1721 г. Россия приобретает статус империи, что дает новый стимул к сложению общенационального русского литературного языка. Происходит дальнейшее упорядочивание лексики, разработка стилистических и семантических норм, язык подвергается нормированности. С этого времени осуществляется активное пополнение словарного состава языка путем многочисленных заимствований для обозначения новых реалий и для совершенствования терминологического аппарата. Так, в манифестах, служащих по сути выражением внетекстуального присутствия высшей власти и потому являющимися образцами деловой словесности на государственном уровне, мы находим заимствования из латинского, в том числе через посредство польского (апелляция, партикулярный, мануфактура, ассигнация, резолючия, ревизия, экспедиция, рапорт), из голландского (форпост, верфь); заимствования из итальянского (процент, каземат, баталия, фабрика, капитал), из немецкого (патент, вексель, партикулярный, герольдия, штат, кассир, штраф), галлицизмы (колика), а также лексику, вошедшую, иногда опосредованно, из других языков, среди которых прослеживается и арабский (тариф).

Лексика делового языка в это время представляется весьма динамичной, несколько отдаляясь от разговорной речи за счет многочисленных заимствований из английского, французского, немецкого и других языков с тем, чтобы затем осуществить обмен языковым материалом. Новые слова, относящиеся к политическому устройству, науке, производству, финансам, военному делу проникали в русский язык почти исключительно через посредство деловой письменности; в дальнейшем взаимодействовали с лексикой других стилей, проникали в нее, обретали новые значения либо исчезали. Иноязычные слова обслуживали определенную сферу, прежде всего, политическую и научную, из-за чего их семантика долгое время могла оставаться размытой, а сами они могли употребляться в различных значениях. В текстах середины XVIII в. нередко встречаются синонимы-дублеты, сосуществующие бок о бок; однако зачастую в дальнейшем одни лексемы оказываются вытеснены другими, что свидетельствует о стремлении к унифицированности и доступности делового письма. Так, постепенно исчезают из делового языка слова конфирмация «подтверждение», пенсион «платеж», маетность «имение», регимент «отряд» и т. п., которые неоднократно встречаются в текстах законов первой половины XVIII в. и исчезают через несколько десятилетий. В это время многие заимствования «начинают преодолевать свою семантическую неопределенность и статичность. Эта тенденция проявляется в тех семантических изменениях, которые претерпевают иноязычные слова в рассматриваемые период. Показателем более глубокого освоения русским языком иноязычных слов является развитие у них новых переносных значений» [20, с. 194]. Так, например, исчезает из делового языка слово сентенщия в значении «решение», развив новый оттенок значения и перейдя в стиль научный.

\footnotetext{
${ }^{1}$ Здесь и далее примеры в современной орфографии приводятся по изданию: Полное собрание законов Российской Империи: [Собрание 1-е. С 1649 по 12 дек. 1825 г.]. - Санкт-Петербург: тип. 2 Отд-ния Собств. е. и. в. канцелярии, 1830-1851.
} 
В истории русского языка отмечается несколько периодов, когда активизировался процесс заимствования за счет слов иноязычного происхождения. Одним из таких этапов является XVIII в. Затронув политическую, социальную, экономическую и другие сферы и будучи нацеленными на перенятие опыта европейских стран, изменения Петра I способствовали усвоению понятий, не существовавших до этого времени в русском обществе, и их номинации. С другой стороны, система слов, взаимодействуя с системой понятий, оказывается системой двусторонней [2, с. 13]. С течением десятилетий сами эти понятия видоизменялись, в связи с чем в одних случаях на смену одним наименованиям приходили новые, точнее отражавшие суть какого-либо явления, а в других - семантика слов развивалась и становилась подчас совершенно иной в сравнении с первоначальной. Новые объекты действительности возникали и изменялись, поэтому с научной точки зрения немалый интерес представляет изучение развития семантики терминов и их функционирования.

Так, одной из наиболее динамично развивавшихся сфер в XVIII в. была экономика. Учреждались различные банки, проводились денежные реформы, усложнялись торговые отношения, причем в большинстве случаях аналогичные изменения происходили в европейских странах, поэтому вполне объяснимо, что в области экономики иноязычная лексика присутствует в немалом количестве.

Новая лексика, относящаяся к финансовой сфере, достаточно разнообразна: в манифестах встречаются слова, заимствованные из церковнославянского (стан), древнерусского (оброк, сбор, цеена), а также из различных европейских языков - либо непосредственно, либо с помощью другого языка (как правило, польского). В то время как термины первых двух пластов, имеющие славянское происхождение, употреблялись к этому времени уже не один век и были обычным делом для современников, элементам третьей группы еще предстояло пройти путь освоения русским языком. Это отразилось и в особых толкованиях значений отдельных слов, а графически - в вариативности написания. Так, например, допускалось различное оформление слов: аппелляция (приближенное к латинскому appellatio) и апелляция (от польского apelacja). В то время как в региональных деловых бумагах подобная неустойчивость наблюдается на протяжении всего XVIII в., на государственном уровне постепенно закрепляется определенное написание, с постоянством воспроизводимое в различных документах. В данном примере нормативным стал второй вариант. Группа заимствований, связанная с посредничеством польского языка, оказывается наиболее многочисленной. Это такие слова, как $n е н-$ сион, конфирмовать, партикулярный, монета, наџия, фабрика, ревизия, комлиссия и др.

Постепенно приспосабливаясь к новой почве, данная лексика прочно закреплялась на определенных позициях, не вытесняясь аналогами из западноевропейских языков. В то же время, тот факт, что большая ее часть восходит к языку латинскому, объясняется католицизмом, господствовавшим в Речи Посполитой, в связи с чем активно переводились и изучались библейские тексты, обогащая польский, а за ним и соседние языки, новыми словами.

Следует отметить важную особенность заимствований: формальные показатели грамматического рода в русском, немецком, французском и других языках если и совпадают, то случайно. К тому же, зачастую флексии в заимствованном слове усекаются, и слово обретает иную родовую принадлежность. Так, например, окончание -е в немецком языке указывает на женский род, это же подтверждает соответствующий артикль. При ассимиляции, в частности, слова die Strafe фонетическое слово сокращается на два слога, при этом, обретая конечный губно-зубной согласный, оно логично начинает восприниматься носителем русского языка как существительное мужского рода. Слово banco в итальянском, имея окончание -o, при переходе в немецкий язык утрачивает его как нехарактерное для последнего, становясь при этом существительным женского рода. При заимствовании же русским языком слово, оканчивающееся на заднеязычный, вновь переходит в грамматический разряд мужского рода. Учитывая, что такие переходы осуществлялись часто, становится объяснимым тот факт, что иногда существительное могло функционировать параллельно, изменяясь по различным парадигмам (сохранив родовую принадлежность языка-источника и обретя новую в языкереципиенте), как в различных функциональных стилях речи, так и в пределах одного. Кроме того, иногда по аналогии оно могло употребляться в роде, совершенно ему не характерном. Так, немецкое слово der Saal мужского рода, заимствованное русским через французское la salle женского рода, стало употребляться в обоих вариантах; но, помимо того, в просторечии получило распространение и в форме среднего рода, имея окончание на редуцированный гласный звук.

Исследуя синтаксическую организацию деловых памятников конца XVIII в., Ш.А. Амади, например, отмечает немаловажный факт, касающийся определения места разговорного языка, просто- 
речий и диалектов в текстах: «При дифференциации примет разговорной, просторечной, диалектной речи, отраженной в деловом письме, важно учитывать, что эти разновидности устной речи обнаруживают общие и специфические показатели. К общим синтаксическим элементам относятся, например, вводные слова, обращения; уточняющие приложения; бессоюзные связи; инверсии; разговорные падежные формы, характерные предложно-падежные формы; преобладание сочинения и присоединения; определенно-личные, неопределенно-личные, безличные, инфинитивные, простые двусоставные предложения. Живая разговорная речь обладает и особым набором синтаксических примет...» $[1$, c. 10]. Автор на основе анализа языкового материала приходит к выводу, что в области синтаксиса в деловых текстах отсутствуют просторечные и диалектные черты, что было достаточно частым явлением до XVIII в.

Говоря о деловом языке XVIII в., исследователи сходятся во мнении, что он представляет собой «сплав искусственных элементов канцелярского стиля и фактов, прямо отражающих живую речь того времени» [9, с. 29]. В.В. Виноградов, характеризуя XVIII в. в истории русского литературного языка, подчеркивает, что сложные преобразования в письменном и народном языках приводят к «сближению стилей литературного языка с системой национального разговорного общенародного языка; к постепенному устранению перегородок, жанровой разобщенности между тремя стилями языка и к созданию единой национально-языковой нормы литературного выражения при многообразии способов ее функционально-речевого использования; и, наконец, к литературной обработке народного просторечия и к формированию устойчивых норм разговорно-литературной речи с нормами литературного языка» [3, с. 22].

Термины «разговорное начало», «письменное начало» в различных вариациях встречаются в работах многих ученых. Говоря о деловой письменности, исследователи приходят к выводу, что она представляет собой «особый тип текстов, изначально ориентированный на живой русский язык и традиционно противопоставляемый книжно-литературным (книжно-славянским, книжным, литературным) памятникам, характеризующимся церковно-славянской языковой основой» $[11$, с. 3$]$.

Многие исследователи указывали на тесную взаимосвязь формирующегося литературного языка с языком официальных документов и памятников, относящихся к делопроизводству. Так, в частности, А.А. Шахматов в «Очерке современного русского литературного языка» высказывал мнение о том, что создание делового, приказного языка в сильной степени облегчило победу идее о слиянии книжного языка с народным [21].

Как отмечает Г.О. Винокур, «в допетровской России существовало два письменных языка, резко противопоставленных один другому по своим культурным функциям. Один, так называемый церковнославянский язык, представлял собой ту разновидность древнерусского письменного слова, которой пользовались книжники эпохи Московского государства, претендовавшие на литературность изложения, и которая получила грамматическую обработку в руководствах по языку XVI-XVII вв. Другой, так называемый приказный язык, служил почти исключительно для деловых надобностей и представлял собой канцелярскую обработку обиходной речи с некоторыми, в общем незначительными, заимствованиями из книжной традиции» [5]. С появлением новых жанров, произведений, представлявших собой переводы с европейских языков, в которых деловая письменность получила новое применение, использование книжных элементов стало бы искусственным и не воспринималось бы должным образом, поэтому они постепенно исчезают. Таким образом, новый деловой язык становится, «гораздо литературнее, в нем много книжных черт и западноевропейских заимствований» $[5$, с. 53$]$.

\section{Заключение}

XVIII в., таким образом, становится переломным моментом для деловой письменности. Делопроизводство становится централизованным и регламентируемым, язык законов начинает активно кодифицироваться. Вследствие этого деловая письменность, ранее тесно связанная с живым повседневным языком, несколько обособляется, используя элементы, не относящиеся к разговорной речи. Можно отметить следующие основные особенности деловой письменности этого периода.

1. Деловая письменность активно развивается, обретает новые функции и выполняет особую роль в государстве нового типа, созданном Петром I.

2. Деловая письменность становится непосредственным предметом изучения общественными и государственными деятелями.

3. Деловая письменность подвергается нормализации, кодификации и обретает системность. 
4. Деловая письменность активно взаимодействует с другими видами языка, подвергается изменениям извне, что особенно заметно на лексическом уровне.

5. Жанры деловой письменности обретают более четкие специфические черты, разграничиваясь друг от друга. Это проявляется в стилистическом выражении, лексическом наполнении и формуляре документов.

Таким образом, мы видим, что развитие государственности способствует расширению функций деловой письменности, повышает ее значимость в общественной жизни страны. С другой стороны, подвергаясь кодификации и приобретая черты стройной системы, деловая письменность способствует дальнейшему развитию общественной и политической жизни страны.

\section{СПИСОК ИСТОЧНИКОВ И ЛИТЕРАТУРЫ}

1. Амади Ш.А. Разговорное и письменное начало в синтаксической организации деловых текстов последней трети XVIII века (на материале тюменских распорядительных, просительных документов и записей допросов): автореф. дисс. ... к. филол. н. Тюмень, 2008.

2. Будагов Р.А. Развитие французской политической терминологии в XVIII веке. М.: Добросвет-2000, 2002. $175 \mathrm{c.}$

3. Виноградов В.В. Вопросы образования русского национального литературного языка // Вопросы языкознания. 1956. № I. С. 3-25.

4. Виноградов В.В. Проблемы литературных языков и закономерностей их образования и развития. М.: Наука, 1967. $136 \mathrm{c}$

5. Винокур Г.О. Русский литературный язык в первой половине XVIII века // История русской литературы: в 10 т. / АН СССР. М.; Л.: Изд-во АН СССР, 1941-1956. Т. 3. С. 51-72.

6. Выхрыстюк М.С. Тобольская письменность XVII-XVIII вв. в аспекте лингвистического источниковедения и исторической стилистики: автореф. дис. ... докт. филол. наук. Челябинск, 2004.

7. Дурново Н.Н. К вопросу о времени распадения общеславянского языка // Sbornk prac I Sjezdu slovanskych filolog v Praze, 1929. Praha, 1931. С. 514-526.

8. Копосов Л.Ф. Нормы деловой письменности и русские грамматики XVIII в. // Вестник Московского государственного областного университета. 2007. №1. С. 67-71.

9. Копосов Л.Ф. Севернорусская деловая письменность XVII-XVIII вв. (орфография, фонетика, морфология). М.: МПУ, 2000. $287 \mathrm{c}$.

10. Косов А.Г. Стандартизация текстов деловых документов XVIII века (на примере документальных жанров, выражающих побуждение к действию) // Деловой язык XVIII века по архивным данным городов Челябинска, Кургана, Тобольска: Сб. ст. Челябинск: Изд-во ГОУ ВПО «ЧГПУ», 2004. С. 7-34.

11. Красивова А.Н. Деловой русский язык: Учебно-практическое пособие. М.: Из-во МФА, 2001.80 с.

12. Никитин О.В. Деловая письменность в истории русского языка (XI-XVIII вв.): автореф. дисс. ... д. филол. н. M.: 2004.

13. Никитин О.В. Деловая письменность в истории русского языка (XI-XVIII вв.): Лингвистические очерки / отв. ред. Л.Ф. Копосов. М.: Флинта: Наука, 2004. 266 с.

14. Никитин О.В. М.Л. Магницкий и его «Краткое руководство к деловой и государственной словесности»// Русская речь. М.: 2006. №5. С. 88-98.

15. Никитин О.В. Проблемы этнолингвистического изучения памятников деловой письменности: Монография. М.: Флинта, Наука, 2000. 204 с.

16. Полное собрание законов Российской империи: Собрание 1-е. В 45 тт. СПб: Тип. ІІ Отд-ния Собств. е. и. в. канцелярии, 1830-1851.

17. Татищев В.Н. Записки. Письма, 1717-1750 гг. / Василий Никитич Татищев; отв. ред. А. И. Юхт; АН СССР. М.: Наука, 1990.

18. Татищев В.Н. Судебник государя царя и великаго князя Иоанна Васильевича, и некоторые сего государя и ближних его преемников указы, / Собранные и примечаниями изъясненные покойным тайным советником и астраханским губернатором Васильем Никитичем Татищевым. М.: При Имп. ун-те, 1768.

19. Успенский Б.А. Краткий очерк истории русского литературного языка (XI - XIX вв). М.: Гнозис, 1994.240 с.

20. Черкасова Е.Т., Смолина К.П., Копорская Е.С. История лексики русского литературного языка конца XVIIначала XIX века. М.: Наука, 1981. 376 с.

21. Шахматов А.А. Синтаксис русского языка / Редакция и комментарии проф. Е.С. Истриной. М.: Эдиториал УРCC, 2001. $624 \mathrm{c}$ 
Чистяков Александр Владимирович, кандидат педагогических наук, старший преподаватель кафедры русского языкознания

Самаркандский государственный университет 140104, Узбекистан, г. Самарканд, Университетский бульвар, 15

E-mail: chistiakov_av@yahoo.com

\title{
A.V. Chistyakov \\ THE DEVELOPMENT OF STATEHOOD IN RUSSIA OF THE XVIII CENTURY AND THE FORMATION OF A NEW TYPE OF BUSINESS WRITING
}

\author{
DOI: $10.35634 / 2412-9534-2021-31-3-438-448$
}

The article is devoted to the development of business writing as an independent style of official document flow in Russia. For centuries, documents have been compiled in a language close to the spoken language and contained the individual speech characteristics of the compiler. This continued until the 18th century, when Peter I accelerated the state centralization and reorganized the system of state administration. These changes made it necessary to systematize the document flow and unify legislative acts. Naturally, such activity has led to the ordering of language of documents. As shown in the article, two main trends in the development of business language can be observed during the 18th century: 1) active enrichment of vocabulary and speech turns due to borrowing and terminologization process, caused by the development of various aspects of social life; 2) isolation of genres, regulation of the form of documents and active formation of terminology. This process, which began in the Petrine era, continued for many decades and was not completed under Catherine II.

Keywords: business writing, codification, norm, style, history of Russian language.

\section{REFERENCES}

1. Amadi Sh.A. Razgovornoe i pis'mennoe nachalo v sintaksicheskoj organizacii delovyh tekstov poslednej treti XVIII veka (na materiale tyumenskih rasporyaditel'nyh, prositel'nyh dokumentov i zapisej doprosov) [Colloquial and written origin in the syntactic organization of business texts of the last third of the XVIII century (based on the material of Tyumen administrative, petitioning documents and records of interrogations)]: synopsis of dissertation.... Cand. of philological science. Tyumen', 2008. (In Russian).

2. Budagov R.A. Razvitie francuzskoj politicheskoj terminologii v XVIII veke [The development of French political terminology in the XVIII century]. Moscow, Dobrosvet-2000, 2002. 175 p. (In Russian).

3. Vinogradov V.V. Voprosy obrazovaniya russkogo nacional'nogo literaturnogo yazyka [Issues on the formation of the Russian national literary language] // Voprosy yazykoznaniya. 1956. № I. P. 3-25. (In Russian).

4. Vinogradov V.V. Problemy literaturnyh yazykov i zakonomernostej ih obrazovaniya i razvitiya [Problems of literary languages and patterns of their formation and development]. Moscow, Nauka, 1967. 136 p. (In Russian).

5. Vinokur G.O. Russkij literaturnyj yazyk v pervoj polovine XVIII veka [Russian literary language in the first half of the XVIII century] // Istoriya russkoj literatury: v 10 t. / AN SSSR. Moscow-Leningrad, Izd-vo AN SSSR, 19411956. Vol. 3. P. 51-72. (In Russian).

6. Vyhrystyuk M.S. Tobol'skaya pis'mennost' XVII-XVIII vv. v aspekte lingvisticheskogo istochnikovedeniya i istoricheskoj stilistik [Tobolsk writing of the XVII-XVIII centuries in the aspect of linguistic source studies and historical stylistics]: synopsis of dissertation.... Cand. of philological science. Chelyabinsk, 2004. (In Russian).

7. Durnovo N.N. K voprosu o vremeni raspadeniya obshcheslavyanskogo yazyka [On the question of the time of the disintegration of the common Slavic language] // Sbornk prac I Sjezdu slovanskych filolog v Praze, 1929. Praha, 1931. P. 514-526. (In Russian).

8. Koposov L.F. Normy delovoj pis'mennosti i russkie grammatiki XVIII v. [Business writing standards and Russian grammars of the XVIII century] // Vestnik Moskovskogo gosudarstvennogo oblastnogo universiteta. 2007. №1. P. 67-71. (In Russian).

9. Koposov L.F. Severnorusskaya delovaya pis'mennost' XVII-XVIII vv. (orfografiya, fonetika, morfologiya) [Russian business writing of the XVII-XVIII centuries (spelling, phonetics, morphology)]. Moscow, MPU, 2000. 287 p. (In Russian)

10. Kosov A.G. Standartizaciya tekstov delovyh dokumentov XVIII veka (na primere dokumental'nyh zhanrov, vyrazhayushchih pobuzhdenie $\mathrm{k}$ dejstviyu) [Standardization of texts of business documents of the XVIII century (on the example of documentary genres that express an incentive to action)] // Delovoj yazyk XVIII veka po arhivnym dannym gorodov Chelyabinska, Kurgana, Tobol'ska: Sb. st. Chelyabinsk: Izd-vo GOU VPO «CHGPU», 2004. P. $7-$ 34. (In Russian). 
11. Krasivova A.N. Delovoj russkij yazyk: Uchebno-prakticheskoe posobie [Business Russian: Educational-practical guide]. Moscow, Iz-vo MFA, 2001. 80 p. (In Russian).

12. Nikitin O.V. Delovaya pis'mennost' v istorii russkogo yazyka (XI-XVIII vv.) [Business writing in the history of the Russian language (XI-XVIII centuries)]: synopsis of dissertation.... Doctor of philological science. M.: 2004. (In Russian).

13. Nikitin O.V. Delovaya pis'mennost' v istorii russkogo yazyka (XI-XVIII vv.): Lingvisticheskie ocherki [Business writing in the history of the Russian language (XI-XVIII centuries): Linguistic essays] / otv. red. L.F. Koposov. Moscow, Flinta: Nauka, 2004. 266 p. (In Russian).

14. Nikitin O.V. M.L. Magnitskij i ego «Kratkoe rukovodstvo k delovoj i gosudarstvennoj slovesnosti» [M.L. Magnitsky and his «Brief guide to business and state speech»] // Russkaya rech'. Moscow, 2006. №5. P. 88-98. (In Russian).

15. Nikitin O.V. Problemy etnolingvisticheskogo izucheniya pamyatnikov delovoj pis'mennosti: Monografiya [Problems of ethnolinguistic study of monuments of business writing: Monograph.]. Moscow, Flinta, Nauka, 2000. 204 p. (In Russian).

16. Polnoe sobranie zakonov Rossijskoj imperii: Sobranie 1-e [Complete collection of laws of the Russian Empire: Collection 1]. V 45 tt. SPb: Tip. II Otd-niya Sobstv. e. i. v. kancelyarii, 1830-1851. (In Russian).

17. Tatishchev V.N. Zapiski. Pis'ma, 1717-1750 gg. [Notes. Letters, 1717-1750] / Vasilij Nikitich Tatishchev; otv. red. A.I. Yuht; AN SSSR. Moscow, Nauka, 1990. (In Russian).

18. Tatishchev V.N. Sudebnik gosudarya carya i velikago knyazya Ioanna Vasil'evicha, i nekotorye sego gosudarya i blizhnih ego preemnikov ukazy [The law of the sovereign Tsar and Grand Prince Ivan Vasilyevich, and some decrees of this Emperor and his immediate successors] / Sobrannye i primechaniyami iz'yasnennye pokojnym tajnym sovetnikom i astrahanskim gubernatorom Vasil'em Nikitichem Tatishchevym". Moscow, Pri Imp. un-te, 1768. (In Russian)

19. Uspenskij B.A. Kratkij ocherk istorii russkogo literaturnogo yazyka (XI-XIX vv) [A brief history of the Russian literary language (XI-XIX centuries)]. Moscow, Gnozis, 1994. 240 p. (In Russian).

20. Cherkasova E.T., Smolina K.P., Koporskaya E.S. Istoriya leksiki russkogo literaturnogo yazyka konca XVIInachala XIX veka [History of the vocabulary of the Russian literary language of the end of the XVII - beginning of the XIX century.]. Moscow, Nauka, 1981. 376 p. (In Russian).

21. Shahmatov A.A. Sintaksis russkogo yazyka [The syntax of the Russian language] / Redakciya i kommentarii prof. E.S. Istrinoj. Moscow, Editorial URSS, 2001. 624 p. (In Russian).

Chistyakov A.V., Candidate of Pedagogy, Senior Lecturer at Department of Russian linguistics

Samarkand State University

Universitetskiy Boulevard, 15, Samarkand, Uzbekistan, 140104

E-mail: chistiakov_av@yahoo.com 